\title{
Cultivation of Intercultural Communication Awareness in Reading Courses for English Majors Under the Background of "One Belt, One Road"
}

\author{
JiYun Tang ${ }^{1, *}$ \\ ${ }^{1}$ Department of Foreign Language and Literature, Tianjin University of Commerce Boustead College, Tianjin, 300384, \\ China \\ *Corresponding author. Email: 6746787@qq.com
}

\begin{abstract}
Under the background of "One Belt, One Road", intercultural communication puts forward new requirements and challenges for intercultural talents. This paper mainly analyzes the significance and existing problems of the cultivation of intercultural communication awareness in the teaching of English majors, and proposes a series of solutions based on these problems. The improvement of English reading is helpful to the cultivation of cross-cultural talents.
\end{abstract}

Keywords: intercultural communication awareness; English reading course; "One Belt, One Road" initiative

\section{INTRODUCTION}

The process of globalization makes the exchanges between different nations and regions become all-round, multi-level and multi-channel. Economic, political, social, and cultural exchanges across countries are becoming more and more frequent. Under the guidance of the "Community of a Shared Future for Mankind", General Secretary Xi Jinping proposed the "One Belt, One Road" initiative. The implementation of this initiative requires professional and technical talents serving infrastructure construction, diplomatic trade and cultural exchanges, as well as other innovative international talents. Facing the exchanges and collisions of diversification and values, the construction of the "Belt and Road" has also created new demands for intercultural talents. Intercultural talents not only need foreign language knowledge and skills, but also need to recognize other cultures different from their own culture, break the stereotype of foreign cultures, develop a global perspective and global perspective, and at the same time absorb foreign cultures, which can enhance our cultural soft power, realize cultural self-confidence, and then enhance the influence of local culture in international communication.

\section{THE SIGNIFICANCE OF \\ CULTIVATING INTERCULTURAL COMMUNICATION AWARENESS}

As the universal language of the world, English undertakes the important tasks of cultural exchanges, civilization dissemination and promotion of economic cooperation.
English talents must not only have solid English communication and translation skills, but also be familiar with the cultural connotations behind the language, especially the cultures of different countries and regions, so as to enhance their intercultural communication skills. As some scholars have said, intercultural communication should understand the etiquette norms and communication rules of different cultures, pay attention to culture-loaded words in English, and pay attention to the importance of non-verbal intercultural communication[1].

In the long historical development process, people of various countries have formed different national cultural values and social customs. If the two sides do not enter the same social background in the economic exchanges, then it is very likely that errors or deviations of understanding will be formed in the communication process, which is very detrimental to the development of two countries. In severe cases, it will also cause communication failures between the two countries. According to the survey, there are 60 countries along the route involved in the Belt and Road Initiative. Therefore, in order to ensure the economic development of our country, we should pay attention to the cultivation of English majors in intercultural communication.

However, some countries in the world do not have an advantage in the international political and economic system, and our country is also very scarce of cultural studies of these countries. Therefore, it is necessary for English teachers to learn and teach students cultural knowledge which they lack in the teaching process, so as to meet our country's growing need for intercultural communication teaching and ensure that students' awareness of intercultural communication is significantly improved. 


\section{THE IMPROVEMENT OF ENGLISH READING ABILITY AND THE CULTIVATION OF INTERCULTURAL TALENTS}

Reading is one of the principal ways for people to acquire knowledge and information, learn culture and broaden their horizons. The reader's understanding and use of the text, the reader's own attitude and habitual behavior towards reading, the relevant knowledge and experience accumulated in previous reading practices, and the comprehensive level of strategic use of this knowledge and experience constitute the "reading". Reading ability is a part of educational, cultural, and ideological ability. The improvement of English reading ability not only means the improvement of English learning ability, communication ability and cross-cultural thinking ability, but also helps to shape the learner's character, improve their cultivation, and broaden their horizons.

Intercultural communication is inseparable from the training of intercultural talents. English learning has opened a window for people's intercultural competence, and the improvement of English reading ability is an important indicator to measure the level of foreign language education. At the same time, the improvement of English reading ability is helpful to the cultivation of highquality intercultural talents. English reading ability reflects people's English language knowledge and ability, and also reflects learners' level of knowledge about foreign historical culture, political economy, science and technology civilization, as well as the level of continuous acquisition of new knowledge in English. In addition, the improvement of English reading ability is an important means to develop learners' international perspectives.

Through English reading, English learners can overcome the barriers of intercultural communication, such as stereotypes, prejudice, racial discrimination, racial superiority, ideological hegemony, cultural shock, etc., and help intercultural communicators understand foreign cultures and thinking, so they can accept foreign cultures, deepen the understanding of one's own culture while making differences, and better carry out the development and dissemination of local culture.

The improvement of English reading ability can change learners' thinking and communication habits, and help the learners develop empathy in daily life and communication, so that they can be able to actively find common symbols in intercultural communication, exert the flexibility of communication, and continuously develop cultural adaptability, so as to enhance the individual's core competitiveness and adaptability.

The improvement of English reading ability can effectively shape the character of learners, and help them to establish a correct outlook on life, values and world, as well as enhance the learners' morality. In international exchanges, in addition to complying with laws and regulations, it is also necessary to comply with corresponding ethical standards. Intercultural communication requires the communicator to think about his own behavior and its consequences from time to time, establish positive interpersonal ethics, and ensure that his behavior has a beneficial impact on himself and his interpersonal partners in cross-cultural communication, so they can establish a relationship of coexistence and co-prosperity in the process of communication.

\section{PROBLEMS EXISTING IN THE CULTIVATION OF INTERCULTURAL AWARENESS IN READING TEACHING FOR ENGLISH MAJORS}

\subsection{Unscientific Methods of Cultivating Intercultural Communication Awareness}

At present, English reading courses for English majors are mainly based on skill training, and most of the teaching focuses on understanding the target language and the training of reading speed. Colleges and universities often specify the appropriate textbooks according to the goals set out in the "Syllabus for English Majors in Colleges and Universities" to train students' reading skills and improve their reading speed and comprehension.

The usual practice is that teachers ask students to read prescribed articles or books, introduce background knowledge in class, explain reading skills, and organize students to do various exercises provided by textbooks. However, this type of class and teaching activities that has lasted for many years is facing challenges. Some students lose interest in English reading classes, and there is a gap between teaching effectiveness and expectations. Since the selected article first focuses on the training of reading skills, content teaching is not the focus of teaching or learning. The scattered knowledge involved in the extensive reading class is difficult to maintain students' stable interest in learning, and it is difficult to maintain their sustained learning motivation.

\subsection{Teachers' Lacking of Intercultural Communication Awareness in the Teaching Process}

In traditional English reading teaching process, teachers only emphasize certain grammatical structures in English articles and the translation of each sentence, which leads students to focus on the superficial meaning of the sentences[2]. And when teaching English reading, some teachers mainly teach students relevant reading skills, and explain some important and difficult vocabulary, without carrying out relevant intercultural communication teaching. Therefore, although students have mastered some English knowledge in a short period of time, they cannot easily carry out certain international exchanges due to their lack of intercultural communication skills. 


\subsection{Students' Weak Awareness of Intercultural Communication}

Many students think that English reading only needs to understand the novel and understand the content of the novel, and it is not necessary to understand the cultural background behind the reading materials, the cultural differences between China and the West, or the cultural differences between countries, regions and ethnic groups in the world. This viewpoint not only limits the improvement of students' intercultural communication skills, but also hinders students' promotion of traditional Chinese culture. In addition, students themselves generally have difficulties in reading English original texts, which also leads to their lack of enthusiasm for pursuing and learning intercultural communication knowledge.

\subsection{Inadequate Reading Materials of Intercultural Communication for the Students}

At present, most of the reading courses for English majors in Chinese colleges and universities use traditional extensive reading textbooks, and there are few specialized intercultural communication reading materials. Even if some college English majors use intercultural communication textbooks, but the layout and design of the materials is not systematic or complete, which makes it easy for students to ignore the cultural knowledge behind the materials after they finish reading.

\subsection{Unscientific Traditional Assessment in English Reading Courses}

The traditional assessment in reading courses for English majors cannot stimulate the cultivation of intercultural communication awareness. At present, because of its inspection and evaluation system, the teaching of English reading courses in colleges and universities still preferentially adopts the traditional examination. So in order to cope with the exam, students often tend to memorize the materials, while ignoring the intercultural communication knowledge behind it. Because students pay too much attention to exams, they often focus on the sentences or paragraphs in reading classes. Reading classes are more similar to intensive reading classes. Such an assessment method cannot stimulate students to consciously develop their own intercultural communication skills in daily learning.

\section{CULTIVATION STRATEGIES OF INTERCULTURAL COMMUNICATION AWARENESS IN READING TEACHING FOR ENGLISH MAJORS}

\subsection{Optimizing the Teaching Methods of Cultivating Intercultural Communication Awareness}

\begin{abstract}
When teachers are teaching English reading, they should optimize their teaching methods and carry out teaching creatively to achieve the "double harvest" of reading teaching and intercultural communication teaching. On the one hand, teachers should intersperse intercultural communication teaching artistically, such as succinctly explaining the folk customs, customs, cultural beliefs, etc. of a certain country or nation. English teachers can also use cultural contrast, cultural introduction, discourse analysis and other methods to cultivate intercultural communication awareness in reading teaching[3].

On the other hand, in the teaching process of extensive reading, teachers can extend the classroom with the help of modern advanced teaching methods, such as a detailed explanation of the intercultural knowledge presented in the reading materials in the form of MOOC. Teachers can also register for WeChat official account to regularly push intercultural teaching information based on reading materials. In order to urge students to learn independently, English teachers can appropriately assign reading material translation tasks and incorporate them into their usual grades. They can also guide students to study cooperatively, supervise each other, answer each other's questions, and jointly solve the problems encountered in reading and intercultural communication learning.
\end{abstract}

\subsection{Enhancing English Teachers' Intercultural Communication Awareness}

English teachers should continuously improve their intercultural communication knowledge and form systematic cognition. The improvement of English teachers' intercultural awareness mainly includes three aspects: first, they must continue to accumulate and consolidate their own intercultural knowledge; second, under the "Belt and Road" initiative, they must be guided by the principle of shared future for human community and actively research and sort out the cultures of countries and regions along the Belt and Road; third, we must carefully study China's traditional and contemporary culture, deepen our understanding, and establish a new teaching concept, which means that intercultural communication training is more than just learning from other countries. We should also learn from our own culture and strengthen international communication. In addition, English teachers must establish multiple values, fully 
respect multiple civilizations, and avoid communicative conflicts during cultural dissemination. They must understand the connections and differences between Chinese and foreign cultures, and improve their conversion skills in the process of intercultural communication.

\subsection{Enhancing Students' Intercultural Awareness}

Different from English teachers, students' intercultural knowledge reserves must consider not only commonality, but also personality development. Students have their own career plans and career choices, so they have preferences for future professions, countries and regions that may be involved. Therefore, English majors should not only have a general overview of various cultures in different countries and regions in the world, but also prepare a targeted cultural knowledge reserve of their preferred regions, and carry out cultural comparisons to cultivate intercultural communication skills. For intercultural knowledge that they don't understand, students should take the initiative to search for information, actively consult teachers, or surf the Internet to solve problems in order to avoid intercultural communication conflicts.

\subsection{Compiling Intercultural Communication Reading Materials for English Majors}

In accordance with the development of the "Belt and Road" initiative and the need to build a community with a shared future for mankind, in the teaching of English reading, teachers should sort out the cultures of various countries in the world, and carefully search for corresponding reading materials, which should be systematic and comprehensive[4]. So that students could be familiar with the cultures of all nations in the world in all aspects during the reading process. It needs to be pointed out that English reading materials should also focus on China's excellent traditional culture and modern culture, because the process of intercultural communication is also that of civilized communication and dissemination.

\subsection{Altering the Traditional Summative Evaluation Mechanism}

The traditional summative evaluation mechanism only focuses on the final exam, which cannot stimulate students to actively read books or cultivate their own intercultural communication awareness. The formative evaluation (preclass preview, book report, oral statement, group discussion, class participation, after-class homework) should be combined with summative evaluation (final exam). The trinity of teacher evaluation, student selfevaluation, and student mutual evaluation should be established, which is an evaluation system covering the whole process before, during and after class. Especially in the process of formative evaluation, it emphasizes the intercultural communication knowledge in the reading process, and encourages and urges students to take the initiative to learn on this aspect.

Formative evaluation and summative evaluation are the evaluation theories proposed by M. Scriven, professor of Harvard University, in "Evaluation Ideologies" in 1967[5] and then introduced into teaching evaluation activities by American educator B.S. Bloom[6]. According to their researches, formative evaluation refers to the interest, attitude, and degree of participation in the learning process of students through a variety of evaluation methods, such as observations, activity records, tests, questionnaires, consultations, interviews, learning logs, and learning files, etc. Their learning progress is continuously evaluated. This evaluation is an effective way to evaluate teachers' teaching and students' learning effects, which emphasizes the timely and effective monitoring of students' acquisition of knowledge and skills in teaching activities. This kind of evaluation throughout the entire learning process can provide key feedback information and promote teaching. At the same time, formative evaluation not only pays attention to the evaluation of teachers to students, but also pays attention to the mutual evaluation and self-evaluation of students, avoiding the one-sidedness caused by the single subject of the summative evaluation.

Compared with formative evaluation, summative evaluation refers to the summative evaluation of the learning effect of students and the teaching effect of teachers, which is mainly carried out in the form of examinations at the end of the semester. Through the assessment, you can grasp the situation and level of students' learning, and at the same time, it can counteract the development of English reading teaching.

Constructing a scientific and efficient course evaluation system plays a vital role in improving the teaching quality of English majors[7]. The formative evaluation and summative evaluation should be combined, with particular emphasis on students' performance in pre-class preparation, reading reports, oral presentations, group discussions, classroom participation, and homework throughout the whole semester. In all teaching and practice links, emphases should be put on the cultivation of crosscultural communication awareness, and improvement of students' independent learning ability, so as to urge them to actively learn cross-cultural communication knowledge Only in this way can we organically combine the content teaching and student growth in English reading teaching. And only in this way can we respond to the call of "One Belt One Road" initiative and cultivate cross-cultural communication talents for our country who can face the challenges of the new era.

\section{CONCLUSION}

In the context of our country's deepening of reforms, expanding opening up, and advancing the "Belt and Road" initiative and the "Building a Community of Shared Future for Mankind" initiative, it is very significant and 
meaningful to cultivate intercultural communication talents and serve the overall situation of our country. The teaching of English reading has strong cultural instruction. Teachers should continuously innovate teaching methods, effectively use English reading to cultivate students' intercultural communication awareness, and improve students' intercultural communication skills, hence providing support for our country to strengthen cooperation with countries around the world. Only in this way, can we cultivate qualified talents for the development of the country and the nation.

At the same time, in order to tell the Chinese story well, it is necessary to establish a systematic and objective understanding of the characteristics and tendencies of cross-cultural communication between different cultures, which can let the world understand China better. At the same time, the improvement of English reading ability can better promote the learners' mother language learning. In a multicultural international society, we will carry forward the traditional culture of our nation, adhere to our national identity and cultural identity, and enhance the influence of our own culture in the international society.

\section{REFERENCES}

[1]Xiaoxia Tang, “ The Infiltration of Intercultural

Communication in College English Education", English Teachers, 2016(19): pp. 15-18. DOI: CNKI: SUN: YJJS.0.2016-19-004

[2]Lili Duan, "The Cultivation of Intercultural Communicative Competence in College English Reading Teaching", Overseas English, 2016(20): pp. 3-
4. DOI: https://www.cnkis.com.cn/Article/CJFDTotalHWYY201620003.htm

[3] Juejing Jiang, “An Analysis of the Cultivation Strategies of Cross-cultural Communication Ability in English Reading Teaching", English Square, 2016(4): pp. 83-84. DOI: 10.16723/j.cnki.yygc.2016.04.042

[4] Hongxin Jiang, "Some Thoughts on the Establishment of Reading Reference List for English Majors", Foreign Language Teaching and Research, 2014(3): pp. 606-613.

[5] Michael Scriven, "Evaluation Ideologies," In: G. F. Madaus, M. Scriven and D. L. Stuffelebeam Eds., Evaluation Models, Klumer-Jijhoff, Boston, 1991, pp. 229-260. DOI: http://dx.doi.org/10.1007/0-306-475596_15

[6] Ronghua Hu, "On the Reform and Development of Assessment System for English Course”, Journal of Guizhou University of Engineering Science, 2019(1): pp. 118-124. DOI:

http://www.cnki.com.cn/Article/CJFDTotalBJSZ201901021.htm

[7] Hongxin Jiang, "Reflections on the Formulation of National Standards for the Teaching Quality of English Majors", Foreign Language Teaching and Research, 2014(3): pp. 456-462. DOI: CNKI:SUN:WJYY.0.201403-012 